\title{
Absorptive capacity: Relevancy for large and small enterprises
}

\author{
Authors: \\ Joshua R. Ndiege ${ }^{1}$ \\ Marlien E. Herselman ${ }^{1,2}$ \\ Stephen V. Flowerday ${ }^{1}$

\section{Affiliations:} \\ ${ }^{1}$ Department of Information \\ Systems, University of Fort \\ Hare, South Africa \\ ${ }^{2}$ Mereka Institute, CSIR, \\ Pretoria, South Africa

\section{Correspondence to:} \\ Joshua Ndiege \\ Email: \\ joshuarumo@yahoo.com \\ Postal address: \\ PO Box 7426, East London \\ 5200 , South Africa \\ Dates: \\ Received: 02 Mar. 2012 \\ Accepted: 26 Apr. 2012 \\ Published: 11 June 2012 \\ How to cite this article: \\ Ndiege, J.R., Herselman, \\ M.E. \& Flowerday, S.V., \\ 2012, 'Absorptive capacity: \\ Relevancy for large and smal \\ enterprises', SA Journal of \\ Information Management \\ 14(1), Art. \#520, 9 pages. \\ http://dx.doi.org/10.4102/ \\ sajim.v14i1.520
}

(C) 2012. The Authors. Licensee: AOSIS OpenJournals. This work is licensed under the Creative Commons Attribution License.
Background: Over the years, there has been a growing interest in organisational research in the absorptive capacity $(\mathrm{AC})$ construct, but only a few theoretical and empirical studies on this topic have been carried out over the last decade. However, a number of scholars and practitioners have continued to cite $\mathrm{AC}$ as a significant factor in determining the success or failure of organisations. With the dramatic changes in business environments, there has been a growing rise in the use of knowledge by organisations to help improve and maintain their competitiveness and consequently their survival. AC is a fundamental element that helps organisations to gain competitive advantage by producing commercial products or services through the transformation of knowledge.

Objective: The purpose of this article is thus to provide a review of the literature on this subject with the aim of finding out how both large and small enterprises stand to benefit from AC. We intend to affirm that, by successfully carrying out a learning process that is characterised by the exploration and exploitation of external knowledge and the organisation's current knowledge base, organisations can realise competitive advantage irrespective of their size.

Method: In the literature search, three approaches were employed, namely academic databases, online search engines and a review of references of related studies which led to more relevant articles and works whose references were further reviewed and analysed. Content analysis was done on all collected articles for quality appraisal and synthesis, the results of which we present as discussions on various sections of this paper leading to answering of our study objective. Only peer-reviewed articles were used.

Results: Our findings reveal that, irrespective of the organisation's size, it can benefit significantly from AC. The study further reveal that AC is a strong predictor of an organisation's performance and hence a strategic asset for the organisation. Organisations with high AC are able to learn how to utilise new knowledge within their processes and come up with changes that improve their competitive advantage.

Conclusion: We submit that, because AC is a strong predictor of an organisation's performance, it is imperative that the necessary measures are taken to improve the levels of AC for all firms, irrespective of their size.

\section{Introduction}

Over the years, there has been a growing interest in organisational research in the absorptive capacity (AC) construct (Lane, Koka \& Pathak 2006; Daghfous 2004). However, few theoretical and empirical studies were carried out on AC over the last decade (Bergh \& Lim 2008; Chen 2004; Cockburn \& Henderson 1998; Cohen \& Levinthal 1990; Deed 2001; Gray 2006; Waalkens, Jorna \& Postma 2004; Zahra \& George 2002). A number of scholars and practitioners have continued to cite $\mathrm{AC}$ as a significant factor in determining whether an organisation is able to acquire and make use of external knowledge to their advantage (Bergh \& Lim 2008; Lenox \& King 2004; Harrington \& Guimaraes 2005). With the dramatic changes in the business environment as a result of technological advancements, increased competition and market globalisation, amongst others, there has been a growing rise in the use of knowledge by organisations to help improve and maintain their competitiveness and consequently their survival (Scarbrough 2008; Higgins \& Aspinall 2011; Cuervo-cazurra \& Annique 2010; Uretsky 2001).

The primary objective of this article is to address the following question through a review of relevant literature: How can both large and small enterprises benefit from absorptive capacity? Methodologically, in conducting this study, we adopted Fink's (2005:3) definition of a research literature review in which he defines it as a 'systematic, explicit and reproducible method for identifying, evaluating and synthesising the existing body of completed and recorded work produced by researchers, scholars, and practitioners.' Guided by this definition, we made use 
of three approaches to the literature search in conducting the literature review for this study. Firstly, we made use of several academic databases such as Academic Publications eJournal, Academic Search and the Directory of Open Access Journal. Relevant keywords like absorptive capacity, knowledge management, organisations, SMEs and small business were used in the search. Secondly, we made use of online search engines. In doing so, the same keywords as in the academic database were employed in various combinations. The use of Boolean operators was employed in both cases to take particular advantage of the instruments. Finally, we collected and reviewed the references of related studies. Such reviews led to more relevant articles and works whose references were further reviewed and analysed. Content analysis was done on all collected articles for quality appraisal and synthesis (Okoli \& Schabram 2010), the results of which we present as discussions on various sections of this paper leading to answering of our study objective. We believe that with this approach, the product of this study is scientific and hence reproducible.

The remainder of this paper is structured as follows: In the next section, we present the meaning of the AC construct, after which the various levels of AC are presented. We then provide a discussion on $\mathrm{AC}$ and organisational performance. Thereafter a presentation is made on AC within small enterprises. We finally draw conclusions on how the study addresses our objective and make recommendations for future research directions in this area.

\section{Understanding absorptive capacity}

A number of studies have been carried out around the AC construct in organisation restructuring (Bergh \& Lim, 2008), information technology (Bi, Yu, Chen \& Qi 2009; HaroDominguez, Arias-Aranda, Llorens-Montes \& Moreno 2007; Harrington \& Guimaraes 2005), knowledge management (Saghali \& Allahverdi 2011; Chen 2004; Tsai \& Wu 2011), service and product innovation (Melkas, Uotila \& Kallio 2010; Nieto \& Quevedo 2005; Stock, Greis\& Fisher 2001), organisational learning (Sun \& Anderson 2010) and business performance (Francalanci \& Morabito 2008).

The term AC was originally coined by Cohen and Levinthal (1990) in the field of business strategy. The term is used to refer to the acquisition of new knowledge and the use of this knowledge to improve the organisation's competitiveness (Lane et al. 2006; Daghfous 2004; Cohen \& Levinthal 1990). Cohen and Levinthal (1990:128) define AC as the organisation's ability to 'recognize the value of new information, assimilate it, and apply it to commercial ends'. Varied definitions of AC were provided by different researchers since the 1990s. Table 1 provides a summary of some of these definitions.

From Table 1, it is clear that there is no straightfoward empirical measure of AC. Lane, Koka \& Pathak (2006) submit that this has not only led to minimal research on how $\mathrm{AC}$ is developed; it has equally resulted in problems with comparing research results.
TABLE 1: Definitions of Absorptive Capacity (own).

\begin{tabular}{|c|c|}
\hline Definition & Author(s) \\
\hline $\begin{array}{l}\text { Ability to recognise the value of new external } \\
\text { knowledge, assimilate it and apply it to } \\
\text { commercial ends }\end{array}$ & Cohen and Levinthal (1990) \\
\hline $\begin{array}{l}\text { A set of skills needed to deal with tacit part } \\
\text { of transferred knowledge and the need to } \\
\text { transform this knowledge }\end{array}$ & Mowery and Oxley (1995) \\
\hline Ability to learn and solve problems & $\operatorname{Kim}(1997)$ \\
\hline $\begin{array}{l}\text { Ability of an organisation to learn from } \\
\text { another }\end{array}$ & Lane and Lubatkin (1998) \\
\hline $\begin{array}{l}\text { Includes evaluation, acquisition, integration, } \\
\text { and the commercial utilisation of new } \\
\text { external knowledge }\end{array}$ & Van Den Bosch et al. (1999) \\
\hline $\begin{array}{l}\text { A set of an organisation's routines and } \\
\text { processes used to acquire, assimilate, } \\
\text { transform and exploit knowledge }\end{array}$ & Zahra and George (2002) \\
\hline $\begin{array}{l}\text { Organisation's ability to learn and act on } \\
\text { scientific findings and technological activities } \\
\text { outside its limit }\end{array}$ & Sun and Anderson (2010) \\
\hline
\end{tabular}

It is also clear from the various definitions of AC (Table 1) that the construct is a multi-dimensional concept that consists of different skills as well as dimensions. Cohen and Levinthal (1990) aptly put it that the AC of an organisation is understood in terms of:

the structure of communication between the external environment and the organization, as well as among the the subunits of the organization, and also the character and distribution of expertise within the organization. (p. 132)

They further observed that AC is largely influenced by the organisation's level of prior related knowledge. That is, without prior related knowledge, an organisation will not have the capability to learn from the new information gleaned from the external environment. Individuals with diverse knowledge within the organisation enhance the chance that the incoming knowledge will relate to the existing knowledge base within the organisation (Chen 2004). In its lowest level, Cohen and Levinthal (1990) view prior related knowledge to include basic abilities or even sometimes just shared language. However, it can also mean being in touch with current scientific or technological trends in a given field.

$\mathrm{AC}$ is a vital connection between external knowledge, the organisation's performance and its capacity to innovate (Volberda, Foss \& Lyles 2010). AC allows organisations to identify new opportunities and integrate these opportunities with the existing knowledge base within their organisations.

From the preceding discussions and the definitions from various authors as presented in Table 1, it can be concluded that $\mathrm{AC}$ is the learning ability that organisations develop to identify external information and knowledge that is important to them, to internalise and to customise it to meet and suit their specific needs and consequently to take advantage of it for the good of the organisation. Two components thus clearly emerge in what constitute AC: communication channels within and across the organisation and the common knowledge that is shared within the organisation.

We consider Zahra and George's (2002) definition of AC to be more accurate since it takes into account the manifestation of the various processes that an organisation would go through to change new knowledge into knowledge that is valuable 
for application by the organisation. Further, this definition largely takes into account various elements mentioned by other authors in their definition of the AC construct (Table 1). As presented in Table 1, however, most researchers have abstracted AC into mainly two dimensions, namely external knowledge acquisition and internal knowledge dissemination. Zahra and George (2002) have included more discrete dimensions of the AC construct in their definition by decomposing it into four different dimensions:

- Acquisition: The ability of an organisation to locate, identify, evaluate and acquire outside knowledge regarded as essential for the survival of the organisation.

- Assimilation: The capability of the organisation to analyse, classify, process, interpret and eventually internalise and comprehend the external knowledge through its own routines. The members of the organisation need to interpret and understand the external knowledge to be able to assimilate and benefit from it.

- Transformation: The ability of the organisation to internalise and convert the newly acquired and assimilated knowledge. It is the capacity of the organisation to bring together the existing knowledge with the newly acquired knowledge. The result is a new cognitive composition derived from apparently dissimilar sets of knowledge.

- Exploitation: The capacity of the organisation to bring together knowledge acquired, assimilated and transformed for application and use in the organisation. This is considered as a strategic dimension for the organisation since it produces the outcomes following the effort to acquire, assimilate and transform knowledge. It is the development of routines that will take advantage of the knowledge for the betterment of the organisation.

Zahra and George (2002) classify the acquisition and assimilation dimensions as potential AC and transformation and exploitation as realised AC. They submit that potential $\mathrm{AC}$ is the ability of an organisation to acquire new external knowledge and assimilate it. Conversely, realised AC is the ability of an organisation to transform the external knowledge and exploit it. Whilst the two concepts (potential AC and realised AC) are closely related, they do refer to different kinds of practices. Potential AC is about learning practices whilst realised $\mathrm{AC}$ is concerned with operating practices (Zahra \& George 2002). Figure 1 is used to illustrate the AC construct as reconceptualised by Zahra and George (2002).

Zahra and George (2002) observe that it is imperative that these dimensions of $\mathrm{AC}$ are managed for an organisation to realise greater performance. Their exposition sufficiently captures the various facets of the $\mathrm{AC}$ construct and has been widely accepted by several researchers (Francalanci \& Morabito 2008; Chen 2004; Daghfous 2004; Haro-Dominguez et al. 2007; Harrington \& Guimaraes 2005; Lenox \& King 2004; Jansen, Van den Bosch \& Volberda 2005).

Brokel and Binder (2007) observe that there are two kinds of knowledge transfers, namely intended and unintended. When individuals deliberately seek knowledge, the transfer is considered intended. Conversely, when actors 'stumble upon' knowledge, the transfer is considered unintended. Brokel and Binder's view of knowledge transfer is in agreement with Ronde and Hussler's (2005) findings in their study of knowledge flows. The study revealed that deliberate knowledge flows have a significant influence on innovation. It is important for organisations not to allow knowledge transfer to take place as a mere coincidence. There needs to be a deliberate initiative by organisations to put in place structures that will facilitate the flow of valuable external knowledge to the organisation.

\section{Levels of absorptive capacity}

$\mathrm{AC}$ has been considered as a multilevel construct that can be found at different levels like the national, industry, interorganisation, a whole organisation, inter-organisation units, organisation units and individual levels (Lane et al. 2006; Daghfous 2004; Bergh \& Lim 2008; Cohen \& Levinthal 1990; Minbaeva, Pedersen \& Bjorkman 2003). Cohen and Levinthal (1990) argue that an organisation's AC depends on the AC of its individual members. This does agree with the general notion that organisational knowledge ultimately exist in the members of the organisation (Felin \& Hesterly 2007). Since knowledge within organisations is possessed by individuals, it is imperative that the organisation establishes structures necessary for sharing this knowledge to enable the optimal

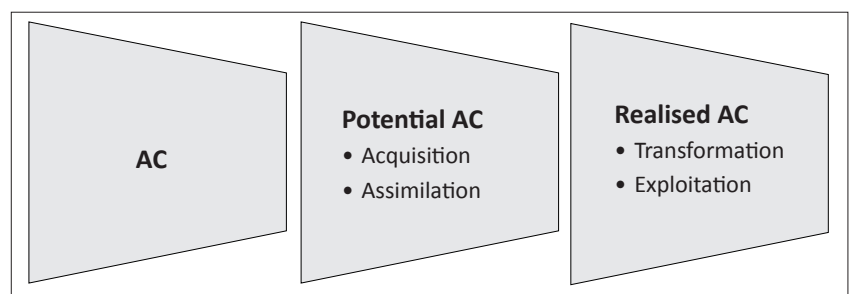

Source: Adapted from Zahra, S. \& George, G., 2002, 'Absorptive Capacity: A Review, reconceptualization, and extension', Academy of Management Review 27(2), 185-203. AC, apsorptive capacity.

FIGURE 1: Absorptive Capacity Construct.

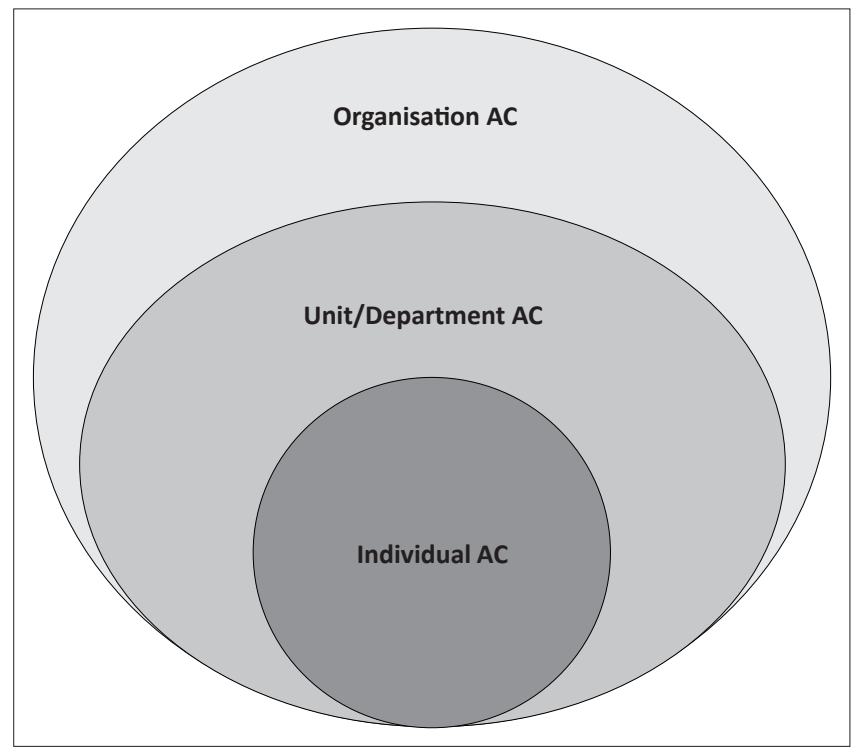

Source: Authors' own data.

AC, apsorptive capacity.

FIGURE 2: An Organisation's Levels of Absorptive Capacity (own). 
utilisation thereof within the organisation. However, Malhotra, Gosain, and El Saw (2005) caution that the AC of an organisation is not just a summation of the employees' $\mathrm{AC}$, but it is the collaboration amongst employees that will bring about the exploitation of new external knowledge, thereby producing successful change.

By decomposing the organisation into individual units and the units to employees within it, we can argue that an organisation's AC is determined by the AC of its individual units and the units' AC consequently is influenced by individuals within them (Minbaeva et al. 2003). Figure 2 illustrates this inter-relationship.

Absorptive capacity in an organisation cannot occur without individual AC (Cohen \& Levinthal 1990), yet individual AC does not equal the organisation's AC. Therefore, to advance the understanding of an organisation's AC, insights into individual AC is important (Volberda et al. 2010). Employees who play a role in the identification, assimilation, application and dissemination of new knowledge are critical for the success of the organisation. For this reason, it is important for organisations to be keen on nurturing the $\mathrm{AC}$ of its individual members. The presence and richness of the structures of knowledge flow within the organisation's units and/or departments will determine the success of knowledge transfer within it. The position of an individual within the organisation's overall network of knowledge flow is also instrumental in determining the individual's ability to acquire and assimilate knowledge from elsewhere in the network (Tsai \& Wu 2011).

Communication channels extending both within and outside of the organisation need to be well developed. A communication channel is the means by which information is transferred from one point to another within a social system (Easterby-Smith \& Lyles 2005:123). Therefore, such channels are critical to AC as they are instrumental in enhancing knowledge flow to and within the organisation. Managers within the organisation have the responsibility of developing their organisation's AC by directly providing information to individuals within the organisation who have the potential to adopt new practices (Lenox \& King 2004). They also need to ensure that the prevailing environment within the organisation is conducive for the discovery, assimilation and exploitation of valuable practices. The transfer of knowledge within the organisation can take place through internal seminars, brochures and demonstrations (Lenox \& King 2004).

An organisation's AC does not only rely on its interface with external environments, but knowledge transfer within and across the organisation's subunits is also critical. Therefore, to understand the source of an organisation's AC, it is imperative to focus on the communication structures between the organisation and the external environment, as well as amongst the organisation's subunits, the character of expertise and their distribution within the organisation.
A number of studies have indicated that an organisation's ability to acquire, assimilate, transform and exploit new knowledge is a critical element in ensuring that it has a sustained competitive advantage. In the next section, the literature review on AC and its effect on the organisation's performance are presented.

\section{Absorptive capacity and organisational performance}

With the substantial uncertainty created by constant changes in the market such as changing preferences of customers, diminishing industry boundaries, changing demographics and social values, emerging competition, new technological advancements and other developments, organisations need to respond swiftly and decisively by making significant changes to their core business practices to avoid the risk of decline or failure. Central to the organisation's ability to respond effectively to market demands is a well developed AC.

Previous studies (Becker \& Peters 2000; Bergh \& Lim 2008; Chen 2004; Daghfous 2004; Gray 2006; Holmqvist 2003 and Saghali \& Allahverdi 2011) have underscored the significant role played by knowledge and organisational learning in enhancing competitive advantage. By exploitation, organisations are able to learn how to improve their capabilities, make use of their present knowledge base and pay attention to existing activities in current domains (Holmqvist 2003). Furthermore, through knowledge routinisation and refinement, exploitation is able to help organisations realise reliability in experience (Holmqvist 2004). An organisation should be able to recognise, anticipate and consequently take action in response to market shifts or new technological developments in a manner that is superior to its competitors.

Whereas organisations that engage in exploitation make use of and enhance their competence, they can also put their energy into the exploration and pursuit of new competence. Exploration for an organisation involves searching for new routines and discovering new ways to businesses, processes, products and technology (Bi et al. 2009). Wiklund and Shepherd (2003) posit that knowledge-based resources have a direct positive influence on an organisation's performance. Darroch (2005) also discovered that organisations with a sound knowledge base and that manage such a resource well make more efficient use of their resources, are better performers and are more innovative.

To adapt to the increasingly competitive and constantly changing business environment, organisations need to develop their AC and exploit it to ensure a sustained competitive advantage. With this, organisations are able to renew themselves by exploiting their current competence and exploring new competence by developing or improving their potential and realised AC. With poor mechanisms for the 
acquisition, assimilation, transformation and exploitation of knowledge, organisations will more likely develop lethargy than responsiveness to market shifts.

A number of studies have been carried out indicating the connection between AC and organisations' performance. These empirical findings indicate the significant role played by AC in fostering organisation's performance as indicated in Table 2.

Organisations with a high AC are always better performers than those with a low AC (Deed 2001; Easterby-Smith \& Lyles 2005; Haro-Dominguez et al. 2007; Melkas et al. 2010). However, the capabilities of an organisation are disadvantaged by a fixed knowledge base, inflexible capabilities and managerial perceptions that are pathdependent (Tripsas \& Gavetti 2000). Because of this, such organisations do not often succeed in recognising and absorbing valuable external knowledge, resulting in stagnation in their growth and eventually an inability to survive in the highly competitive market environment. The AC of an organisation determines its ability to explore and exploit both external knowledge and its existing knowledge base. As a result, AC is a fundamental element that helps organisations to gain competitive advantage by producing a commercial product or service through the transformation of knowledge.

In their study, Teece, Pisano and Shuen (1997) submit that organisations that operate in environments with technological opportunities can benefit more if they have high levels of AC. With technological innovations constantly gaining momentum in the present era, organisations cannot afford to be caught napping. They need to be alive to the realities of these advancements and be ready and willing to exploit them to improve their business. However, the presence of technological opportunities in a given field does not imply that all organisations in that field are necessarily affected with the same level of intensity. The extent to which organisations exploit such opportunities will largely be influenced by the knowledge and the capacities they have at their disposal. Organisations that pose a critical mass of knowledge and have the capacity to absorb are the ones that are able to exploit technological opportunities (Nieto \& Quevedo 2005). Therefore, the presence of AC is critical in organisations' efforts to exploit the pool of technological opportunities in their domain.

By comparison to large organisations, small enterprises have received less attention in $\mathrm{AC}$ research. In the following section, the literature review with regard to $\mathrm{AC}$ within small enterprises is presented.

\section{Absorptive capacity within small enterprises}

We begin by defining small enterprises and differentiating them from large organisations. Various indicators have been used to define small enterprises across the world. Research
TABLE 2: Effects of absorptive capacity (AC) on organisations (own).

\begin{tabular}{ll}
\hline $\begin{array}{l}\text { The effect of AC on an } \\
\text { organisation }\end{array}$ & Illustrative reference \\
\hline $\begin{array}{l}\text { Innovative performance; } \\
\text { exploration or } \\
\text { exploitation; new } \\
\text { product development }\end{array}$ & $\begin{array}{l}\text { Cohen and Levinthal (1990); Tsai (2001); Van Wijk, Van } \\
\text { den Bosch and Volberda (2001); Stock et al. (2001) and } \\
\text { Melkas et al. (2010) }\end{array}$ \\
$\begin{array}{ll}\text { Expectation formation; } \\
\text { reactive or proactive } \\
\text { strategy formation }\end{array}$ & $\begin{array}{l}\text { Cohen and Levinthal (1990) and Van Den Bosch et al. } \\
\text { (1999) }\end{array}$ \\
$\begin{array}{ll}\text { Information systems } \\
\text { integration; IT success }\end{array}$ & $\begin{array}{l}\text { Francalanci and Morabito (2008) and Harrington and } \\
\text { Guimaraes (2005) }\end{array}$ \\
\hline $\begin{array}{l}\text { Information quality } \\
\text { Melkas et al. (2010) }\end{array}$ \\
\hline
\end{tabular}

Source: Authors' own data

TABLE 3: United Kingdom's definition of small enterprises.

\begin{tabular}{lll}
\hline Criteria & Small Firm & Medium Firm \\
\hline Turnover & Not more than $\mathrm{f2.8}$ million & Not more than $\mathrm{f11.2} \mathrm{million}$ \\
Balance sheet & Not more than $\mathrm{f1.4}$ million & Not more than $£ 5.6$ million \\
Employees & Not more than 50 & Not more than 250 \\
\hline
\end{tabular}

Source: Adapted from Deakins, D., 1999, Entrepreneurship and Small Firms, 2nd edn., McGraw-Hill, London.

TABLE 4: European Union's definition of small enterprises.

\begin{tabular}{llll}
\hline Criteria & Micro & Small & Medium \\
\hline Maximum employee & 9 & 49 & 249 \\
Maximum turnover & - & $€ 7$ million & $€ 40$ million \\
Maximum balance sheet & - & $€ 5$ million & $€ 27$ million \\
\hline
\end{tabular}

Source: Adapted from Burns, P., 2001, Entrepreneurship and Small Business, Palgrave, New York.

TABLE 5: Small Business Administration of the United States of America's definition of small enterprises.

\begin{tabular}{lllll}
\hline Criteria & Very Small & Small & Medium & Large \\
\hline Number of employees & Less than 20 & $20-99$ & $100-499$ & Over 500 \\
\hline
\end{tabular}

Source: Adapted from Megainson, Byrd, M. \& Merginson, W. 2008, Small Business Management: An Entrepreneur's Guidebook, 4th edn., McGraw-Hill, New York.

TABLE 6: Republic of Tanzania's definition of small enterprises.

\begin{tabular}{lllll}
\hline Criteria & Micro & Small & Medium & Large \\
\hline Number of employees & Less than 5 & $5-49$ & $50-99$ & Over 100 \\
$\begin{array}{l}\text { Capital investment } \\
\text { (In millions) }\end{array}$ & Tsh. 5 & Tsh. 200 & Tsh. 800 & $\begin{array}{l}\text { Above Tsh. } \\
800\end{array}$ \\
\hline
\end{tabular}

Source: Adapted from Ngasongwa, J., 2002, Ministry of Industry and Trade, Republic of Tanzania, viewed 27 June 2010, from http://www.tanzania.go.tz/pdf/smepolicy.pdf

TABLE 7: World Bank's definition of small enterprises.

\begin{tabular}{lll}
\hline Criteria & Small & Medium \\
\hline Number of employees & Up to 50 & Up to 300 \\
Total assets & Up to $\$ 3$ million & Up to $\$ 15$ million \\
Total sales & Up to $\$ 3$ million & Up to $\$ 15$ million \\
\hline
\end{tabular}

Source: Adapted from International Finance Group, 2012, SME Definition, viewed 13 July 2010, from http://www.ifc.org/sme/html/sme_definitions.html

and literature have also highlighted the definitional problems of small enterprises. There is no generally accepted or agreed upon definition for the term small enterprise (Culkin \& Smith 2000). Organisations vary in size, location, nature of business, financial performance, maturity and management. These variations make it impossible for various researchers to agree on an objective measure to apply when defining small enterprises. Their definitions vary from country to country with different criteria used to classify them in order to address each country's political and economic purposes. Table 3 to Table 7 provide some examples in this regard. 
From the definitions presented in Table 3 to Table 7, it is clear that the general indicators adopted for the definition of small enterprises are the number of employees, sales turnover and total assets. These variations in the definitions can make it difficult for researchers to compare different studies on small enterprises. In this study, therefore, any reference to small enterprises by other authors may range in its definition.

Despite being considered as the drivers of modern economies and thus always being indispensable, small enterprises still lack the proper and adequate application of modern concepts due to their small size (Ayyagari, Beck \& Demirguc-Kunt 2007). Small enterprises often operate under challenging conditions and are further subjected to global pressures from large organisations and demands from customers. As a result, many of them remain unstable and vulnerable. In order to survive in the now highly competitive environment, small enterprises cannot afford to stagnate. They have to be willing and ready to be open to new ideas, new ways of carrying out their operations, new equipments and tools. They should also develop and have the ability to absorb as well as benefit from better ideas, modern ways of performing their operations and current equipment and tools.

Small enterprises provide an interesting and unique context for the exploration of $\mathrm{AC}$ due to the unique characteristics that separate them from large organisations. For example, most of them have limited resources in terms of finance, expertise and time (Agbeibor 2006). Furthermore, they tend to rely heavily upon the motivation and the expertise of their owner or manager. However, small enterprises have always been considered to be critical for the growth and development of any economy. Because of this, they will always have a special economic role to play.

Since small enterprises are often dominated by their owners or managers (Ayyagari et al. 2007), their culture are easily influenced by the leadership style and personality of their owners or managers (Wong \& Aspinwall 2004). For this reason, the commonly held view that these enterprises have a flexible and open culture should be treated with some caution (Wiesner, McDonald \& Banham 2007). It can thus be argued that the small enterprise owner or manager plays a central role in ensuring that information flows within and from outside the organisation. Hence, the AC of small enterprises will most certainly be influenced by their owners'or managers' AC. In their study on small enterprises in Iran, Talebi and Tajeddin (2011) revealed that those enterprises whose owners or managers and employees had high levels of education as well as clear growth objectives had a better capacity to acquire, assimilate and make use of new knowledge.

Small enterprises can use AC for tactical as well as for strategic purposes (Egbu, Hari \& Renukappa 2005; Gray 2006). For tactical purposes, they can use their AC to react to their internal processing needs by using it to revamp their processes. Conversely, strategically they can make use of their $\mathrm{AC}$ to create knowledge that can be exploited for strategic planning. A study by Francalanci and Morabito (2008) revealed that small enterprises' AC has a mediation effect on business performance as well as on the integration of information systems.

Some organisations have a higher capability to absorb, diffuse and utilise knowledge than others (Cohen \& Levinthal 1990). Organisations with more flexible structures are believed to be associated with greater capacities for knowledge acquisition (Bergh \& Lim 2008). Because of their small size, small enterprises are always considered as highly flexible (Levy \& Powell 2000), and they can exploit this flexibility to their advantage by encouraging knowledge transfer processes through the promotion of openness by its employees towards new external stimuli. This can be achieved by promoting collaboration and the exchange of knowledge within the organisation.

With regard to culture, behaviour and structure, small enterprises differ considerably from large organisations. The regular trend in small enterprises are social informal networking (Egbu et al. 2005), a flat and uncomplicated structure that is primarily operations-oriented (Wong \& Aspinwall 2004). Such features are certainly conducive for AC to flourish (Daghfous 2004). Furthermore, such environments can promote flexibility and adaptiveness which may help to overcome resistance to change and create a better alignment to environmental changes and influences (Wiesner et al. 2007). Wong and Aspinwall (2004), however, observe that workers within small enterprises are mainly generalists who perform a number of tasks with a minimal degree of specialisation. This is likely to lead to lack of deep knowledge. Yao, Othman, Abdalla, and Jing (2011) further observe that a number of employees within small enterprises are not willing to share their knowledge due to the lack of a sense of benefit for doing so or a lack of reward for such efforts.

Due to their small size and resource constraints, we can expect small enterprises to have low levels of AC, a less developed approach towards AC, a lack of awareness of the relevance of $\mathrm{AC}$ and no sound understanding of the processes of knowledge acquisition, assimilation, transformation and exploitation. Furthermore, those small enterprises that tend to practice elements of AC do so in an ad hoc manner and relegate such ventures to the category of luxury, with most preferring to adopt the 'wait and see' approach. That is, they wait for large organisations to venture before they take action (Serenko, Bontis \& Hardie 2007). It is therefore imperative that understanding in this field is developed for small enterprises.

\section{Conclusion}

AC can be considered as the ability of an organisation to carry out successfully a learning process that is characterised by the exploration and exploitation of external knowledge and the organisation's current knowledge base in order to 
achieve a competitive advantage. AC is therefore a strong predictor of organisations' performance and hence a strategic asset for the organisation. Organisations with a high AC are able to learn how to utilise new knowledge within their processes and to come up with changes that improve their competitive advantage.

It was made clear from the literature presented in this study that, irrespective of an organisation's size, AC is a critical factor for success. Whilst large enterprises have adequate resources and well-established structures, they can exploit these to help improve and benefit from AC. Conversely, small enterprises can use their small size and flexibility to improve their AC as they can easily adjust and accommodate changes with far less effort than would large organisations. Further, with the turbulent business environment, no organisations can risk stagnation. They have to be able to adapt their practices constantly in the light of environmental changes. It will be an uphill battle if enterprises cannot 'listen' to environmental shifts or exploit new vital external information to enable them to strategically position themselves.

The literature review conducted in this study was instrumental in addressing our research question which was: How can both large and small enterprises benefit from absorptive capacity? The answer is that, through AC, organisations (whether large or small) can benefit in the following ways:

- use AC for new product development

- improve their strategies

- integrate their information systems

- react and adapt to market shifts

- position themselves to better respond to the needs of their customers

- create cohesion between members of the organisation

- better flow of information and/or communication within and out the organisation

- take advantage of external valuable information.

We use Table 8 below to summarise, at a high level, how the literature in this study was instrumental in answering our research question.

We conclude that organisations (whether large or small) need to have properly developed capabilities in external knowledge acquisition and assimilation and intraorganisational knowledge transformation and exploitation in order to sustain their competitiveness. AC is no longer a preserve for large organisations, but it has become highly relevant for small enterprises as well.

From the literature review conducted in this study, we propose certain future research directions in the next section.

\section{Future research directions}

A number of related areas were revealed in this study that could be exploited in order to extend the current research in this field.
TABLE 8: How the literature study addressed the research question (own).

\begin{tabular}{|c|c|c|}
\hline $\begin{array}{l}\text { Heading from the } \\
\text { literature }\end{array}$ & $\begin{array}{l}\text { Contribution to study } \\
\text { objective }\end{array}$ & Illustrative reference \\
\hline $\begin{array}{l}\text { Understanding Absorptive } \\
\text { Capacity (AC) }\end{array}$ & $\begin{array}{l}\text { Understanding various } \\
\text { elements of } A C \text { and } \\
\text { how they are realised }\end{array}$ & $\begin{array}{l}\text { Cohen and Levinthal (1990); } \\
\text { Sun and Anderson (2010); } \\
\text { Van Den Bosch et al. (1999); } \\
\text { Volberda et al. (2010); Lane } \\
\text { et al. (2006) and Zahra and } \\
\text { George (2002) }\end{array}$ \\
\hline $\begin{array}{l}\text { Levels of Absorptive } \\
\text { Capacity (AC) }\end{array}$ & $\begin{array}{l}\text { Organisational units } \\
\text { and workers' role in } \\
\text { firm's } A C \text { and how } \\
\text { they are potential } \\
\text { beneficiaries }\end{array}$ & $\begin{array}{l}\text { Bergh and Lim (2008); } \\
\text { Cohen and Levinthal (1990); } \\
\text { Daghfous (2004); Lane et al. } \\
\text { (2006); Lenox and King (2004); } \\
\text { Minbaeva et al. (2003) and } \\
\text { Tsai and Wu (2011) }\end{array}$ \\
\hline $\begin{array}{l}\text { Absorptive Capacity } \\
\text { and organisational } \\
\text { performance (AC) }\end{array}$ & $\begin{array}{l}\text { Overall benefit } \\
\text { organisations would } \\
\text { derive from AC }\end{array}$ & $\begin{array}{l}\text { Cohen and Levinthal (1990); } \\
\text { Harrington and Guimaraes } \\
\text { (2005); Melkas et al. (2010); } \\
\text { Nieto and Quevedo (2005); } \\
\text { Stock et al. (2001); Tsai (2001) } \\
\text { and Van Wijk et al. (2001) }\end{array}$ \\
\hline $\begin{array}{l}\text { Absorptive capacity within } \\
\text { small enterprises (AC) }\end{array}$ & $\begin{array}{l}\text { What makes small } \\
\text { enterprises have } \\
\text { low levels of AC and } \\
\text { features about small } \\
\text { enterprises that could } \\
\text { make them exploit AC }\end{array}$ & $\begin{array}{l}\text { Agbeibor (2006); Ayyagari } \\
\text { et al. (2007); Serenko et al. } \\
\text { (2007) Wiesner et al. (2007); } \\
\text { Wong and Aspinwall (2004) } \\
\text { and Yao et al. (2011) }\end{array}$ \\
\hline
\end{tabular}

Source: Authors' own data

- As observed by Murovec and Prodan (2009), Bergh and Lim (2008), Harrington and Guimaraes (2005) and Spithhoven et al. (2010), the subject of AC has not been adequately researched. Our study too found scanty literature on the subject. Therefore, there is still a strong need for further research into this area to confirm already produced empirical findings or to determine their generalisability and to reveal further new insights.

- Additionally there is a lack of a commonly agreed upon measurements for AC. It is important that further work be carried out particularly on the measurement of AC in order to reach a common stand or at least a largely acceptable measurement for the construct.

- We also found very few studies conducted in this field within the context of developing countries. It would be interesting to study AC within organisations in developing countries and compare this to those that have been carried out in developed countries. Such research would certainly reveal new insights in this field that would no doubt be of interest to the research community in the area.

\section{Acknowledgements Competing interests}

The authors declare that they have no financial or personal relationship(s) which may have inappropriately influenced them in writing this paper.

\section{Authors' contributions}

J.N. (University of Fort Hare) wrote the article and contributed to the review, discussions on the results, implications and commented on the manuscript at all stages. M.E.H. (University of Fort Hare) contributed to the review, discussions on the results, implications and commented on the manuscript at all stages. S.V.F. (University of Fort Hare) contributed to the review, discussions on the results, implications and commented on the manuscript at all stages. 


\section{References}

Agbeibor, J., 2006, 'Pro-poor economic growth: Role of small and medium size enterprises', Journal of Asian Economics 17(1), 35-40. http://dx.doi.org/10.1016/j. asieco.2006.01.005

Ayyagari, M., Beck, T. \& Demirguc-Kunt, A., 2007, 'Small and medium enterprises across the Globe', Small business Economics 29, 415-434. http://dx.doi. org/10.1007/s11187-006-9002-5

Becker, W. \& Peters, J., 2000, 'Technological opportunities, absorptive capacity and innovation', Eighth International Joseph A. Schumpeter Society Conference. Center for Research in Innovation and Competition (CRIC), Manchester, UK, June 28 - July 01, 2000, pp. 1-38.

Bergh, D.D., \& Lim, E.N.-K., 2008, 'Learning how to restructure: Absorptive capacity and improvisational views of restructuring actions and performance', Strategic Management Journal 29(6), 593-616, viewed 15 January 2012, from http:// onlinelibrary.wiley.com/doi/10.1002/smj.676/pdf

Bi, X., Yu, C., Chen, T. \& Qi, X., 2009, 'Absorptive capacity: Enhancing the absorption of information technology', Management and Service Science, MASS '09 International Conference, Wuhan, China, September 20-22, 2009, pp. 1-4.

Brokel, T. \& Binder, M., 2007, 'The regional dimensions of knowledge transfers - A behavioral approach', Industry and Innovation 14(2), 151-175. http://dx.doi. org/10.1080/13662710701252500

Burns, P., 2001, Entrepreneurship and Small Business, Palgrave, New York.

Chen, C.-J., 2004, 'The effects of knowledge attribute, allience characteristics, and absorptive capacity on knowledge transfer performance', $R$ \& $D$ Management 34(3), 311-321. http://dx.doi.org/10.1111/j.1467-9310.2004.00341.x

Cockburn, I.M. \& Henderson, R N., 1998, 'Absorptive capacity, coauthoring behaviour, and the organization of research in drug discovery', Journal of Industrial Economics 46(2), 157-182. http://dx.doi.org/10.1111/1467-6451.00067

Cohen, W.A. \& Levinthal, D.A., 1990, 'Absorptive capacity: A new perspective on learning and innovation', Administrative Science Quarterly 39, 128-152. http:// dx.doi.org/10.2307/2393553

Cuervo-cazurra, A. \& Annique, U.C., 2010, 'Why some firms never invest in formal R \& D', Strategic Management Journal 31(7), 759-779, viewed 22 November 2011 from http://onlinelibrary.wiley.com/doi/10.1002/smj.836/pdf

Culkin, N. \& Smith, D, 2000, 'An emotional business: A guide to understanding the motivations of small business takers', Qualitative Market Research: An International Journal 3(3), 145-157.

Daghfous, A., 2004, 'Absorptive capacity and the implementation of knowledge intensive best practices', Society for Advancement of Management Journal, Spring, 21-27.

Deakins, D., 1999, Entrepreneurship and Small Firms, 2nd edn., McGraw-Hill, London.

Deed, D.L., 2001, 'The role of R\&D intensity, technical development, and absorptive capacity in creating entrepreneurial wealth in high technology start-ups', Journal of Engineering and Technology Management 18, 29-47. http://dx.doi. org/10.1016/S0923-4748(00)00032-1

Easterby-Smith, M. \& Lyles, M.A., 2005, The Blackwell handbook of organizational learning and knowledge management, illustrated edn., Blackwell, Wiley.

Egbu, C.O., Hari, S., \& Renukappa, S.H., 2005, 'Knowledge management for sustainable competitiveness in small and medium surveying practices', Structural Survey 23(1), 7-21. http://dx.doi.org/10.1108/02630800510586871

Felin, T. \& Hesterly, W.S., 2007, 'The knowledge-based view, nested heterogeneity, and new value creation: Philosophical considerations on the locus of knowledge',
Academy of Management Review 32, 195-218. http://dx.doi.org/10.5465/ Academy of Manage
AMR.2007.23464020

Fink, A., 2005, Conducting research literature reviews: From the internet to paper, Sage Publications, Thousand Oaks.

Francalanci, C. \& Morabito, V., 2008, 'IS integration and business performance: The mediation effect of organizational absorptive capacity in SMEs', Journal of Information Technology 23, 297-312. http://dx.doi.org/10.1057/jit.2008.18 Gray, C., 2006, 'Absorptive capacity, knowledge management and innovation in
entrepreneurial small firms', International Journal of Entrepreneurial Behavior \& Research 12(6), 345-360. http://dx.doi.org/10.1108/13552550610710144

Haro-Dominguez, M.D., Arias-Aranda, D., Llorens-Montes, F.J. \& Moreno, A.R., 2007, 'The impact of absorptive capacity on technological acquisition engineering consulting company', Technovation 27(8), 417-425. http://dx.doi.org/10.1016/j. technovation.2007.04.003

Harrington, S.J. \& Guimaraes, T., 2005, 'Corporate culture, absorptive capacity and IT success', Organization and Management 15(1), 39-63.

Higgins, D. \& Aspinall, C., 2011, 'Learning to learn: a case for developing small firm owner/managers, Journal of Small Business and Enterprise Development 18(1) 43-57. http://dx.doi.org/10.1108/14626001111106424

Holmqvist, M., 2003, 'A dynamic model of intra - and interorganizational learning', Organizational Studies 24, 95-123. http://dx.doi.org/10.1177/ 0170840603024001684

Holmqvist, M., 2004, 'Experiential learning processes of exploitation and exploration', An empirical study of product development, Organizational Science 15, 70-81. http://dx.doi.org/10.1287/orsc.1030.0056

International Finance Group, 2012, SME Definition, viewed 13 July 2010, from http:// www.ifc.org/sme/html/sme_definitions.html
Jansen, J.J., Van den Bosch, F.A. \& Volberda, H.W., 2005, 'Managing potential and realized absorptive capacity: How do organizations antecedents matter?', Academy of Management Journal 48(6), 999-1015. http://dx.doi.org/10.5465/ Academy of Manag
AMJ.2005.19573106

Kim, L., 1997, 'The dynamics of Samsung's technological learning in semiconductors', California Management Review 39, 86-100.

Lane, P.J. \& Lubatkin, M., 1998, 'Relative absorptive capacity and interorganizational learning', Strategic Management Journal 19(5), 461-477, viewed 17 November 2011, from http://onlinelibrary.wiley.com/doi/10.1002/(SICI)10970266(199805) 19:5\%3C461::AID-SMJ953\%3E3.0.CO;2-L/pdf, http://dx.doi.org/10.5465/AMR.2006. 22527456

Lane, P. J., Koka, B. \& Pathak, S., 2006, 'The reification of absorptive capacity: A critical review and rejuvenation of the construct', Academy of Management Review 31(4), 833-863.

Lenox, M. \& King, A., 2004, 'Prospects for developing absorptive capacity through Internal Information Provision', Strategic Management Journal 25(4), 331-345 viewed 20 February 2012, from http://onlinelibrary.wiley.com/doi/10.1002/ smj.379/pdf

Levy, M. \& Powell, P., 2000, 'Information systems strategies for small and mediumsized enterprises: an organisational perspective', Journal of Strategic Information Systems 9(1), 63-84. http://dx.doi.org/10.1016/S0963-8687(00)00028-7

Malhotra, A., Gosain, S. \& El Saw, O.A., 2005, 'Configuration in supply chains: Gearing for partner-enabled market knowledge creation', MIS Quarterly 29(1), 145-187.

Megginson, L., Byrd, M. \& Megginson, W., 2008, Small Business Management: An Entrepreneur's Guidebook, 4th edn., McGraw-Hill, New York.

Melkas, H., Uotila, T. \& Kallio, A., 2010, 'Information quality and absorptive capacity in service and product innovation proceses', Interdisciplinary Journal of Information, Knowledge, and Management 5, 357-373.

Minbaeva, D., Pedersen, T. \& Bjorkman, I., 2003, 'MNC knowledge transfer, subsidiary absorptive capacity, and HRM', Journal of International Business Studies 34(6), 586-599. http://dx.doi.org/10.1057/palgrave.jibs.8400056

Mowery, D.C. \& Oxley, J.E., 1995, 'Inward technology transfer and competitiveness: The role of national innovation systems', Cambridge Journal of Economics 19, 67-93.

Murovec, N. \& Prodan, I., 2009, 'Absorptive capacity, its determinants, and influence on innovation output: Cross-cultural validation of the structural model', Technovation 29, 859-872. http://dx.doi.org/10.1016/j.technovation.2009.05.010

Nalo, S. (2008, February Tuesday), Launch of MSME Case Studies - 2008, Ministry of Industrialisation, Nairobi, Kenya.

Ngasongwa, J., 2002, Ministry of Industry and Trade, Republic of Tanzania, viewed 27 June 2010, from http://www.tanzania.go.tz/pdf/smepolicy.pdf

Nieto, M. \& Quevedo, P., 2005, 'Absorptive capacity, technological opportunity, knowledge spillovers, and innovative effort', Technovation 25(10), 1141-1157. http://dx.doi.org/10.1016/j.technovation.2004.05.001

Okoli, C. \& Schabram, K., 2010, 'A guide to conducting a systematic literature review of information system research', Sprouts: Working Papers on Information Systems 10(26), 1-51

Ronde, P. \& Hussler, C., 2005, 'Innovation in regions: What does really matter?', Research Policy 34(8), 1150-1172. http://dx.doi.org/10.1016/j.respol.2005.03.011

Saghali, A. \& Allahverdi, S., 2011, The intervening role of organizational dynamic routines: Absorptive capacity and knowledge management perspective. 2011 International Conference on Economics and Finance Research, Singapore, February 26-28, 2011, pp. 354-358.

Scarbrough, H., 2008, The evolution of business knowledge (illustrated edn.), Oxford University Press, New York.

Serenko, A., Bontis, N. \& Hardie, T., 2007, 'Organizational size and knowledge flow: A proposed theoretical link', Journal of Intellectual Capital 8(4), 610-627. http:// dx.doi.org/10.1108/14691930710830783

Spithoven, A., Clarysse, B. \& Knockaert, M., 2010, 'Building absorptive capacity to organize inbound open innovation in traditional industries', Technovation 30(2), 130-141. http://dx.doi.org/10.1016/j.technovation.2009.08.004

Stock, G.N., Greis, N.P. \& Fisher, W.A., 2001, 'Absorptive capacity and new product development', The Journal of High Technology Management Research 12(1), 77-91.

Sun, P.Y. \& Anderson, M.H., 2010, 'An examination of the relationship between absorptive capacity and orgnizational learning, and proposed integration', International Journal of Management Reviews 12(2), 130-150. http://dx.doi. org/10.1111/j.1468-2370.2008.00256.x

Talebi, K. \& Tajeddin, M., 2011, 'The adoption of new and innovative knowledge b small and medium enterprises of Iran: Opportunities and constraints for growth', African Journal of Business Management 5(1), 39-49, viewed 10 February 2012, African Journal of Business Management 5(1),
from http://www.academicjournals.org/AJBM

Teece, D.J., Pisano, G. \& Shuen, A., 1997, 'Dynamic capabilities and strategic management', Strategic Management Journal 18(7), 509-533. http://dx.doi. org/10.1002/(SICI)1097-0266(199708)18:7<509::AID-SMJ882>3.0.CO;2-Z

Tripsas, M. \& Gavetti, G., 2000, 'Capabilities, cognition and inertia: Evidence from digital imaging', Strategic Management Journal , 21(10/11), 1147-1162, viewed 22 February 2012, from http://onlinelibrary.wiley.com/doi/10.1002/1097-0266 (200010/11)21:10/11\%3C1147::AID-SMJ128\%3E3.0.CO;2-R/pdf 
Tsai, W., 2001, 'Knowledge transfer in intraorganizational networks: effects of networks position and absorptive capacity on business unit innovation and networks position and absorptive capacity on business unit innovation and org/10.2307/3069443

Tsai, Y.C. \& Wu, C.S., 2011, 'The effect of interpartner resource alignment and absorptive capacity on knowledge transfer performance', African Journal of Business Management 5(26), 10434-10445, viewed 23 February 2012, from, http://www.academicjournals.org/AJBM

Uretsky, M., 2001, 'Preparing for the real knowledge organization', Journal of Organizational Excellence 21(1), 87-93. http://dx.doi.org/10.1002/npr.1122

Van den Bosch, F.A., Volberda, H.W. \& De Boer, M., 1999, 'Coevolution of firm absorptive capacity and knowledge environment: Organizational forms and combinative capabilities', Organization Science 10(5), 551-568. http://dx.doi. org/10.1287/orsc.10.5.551

Van Wijk, R., Van den Bosch, F.A. \& Volberda, H.W., 2001, The impact of the depth and breadth of knowledge absorbed on levels of exploration and exploitation. Insights into knowledge transfer, BPS Division, Washington DC.

Volberda, H.W., Foss, N. \& Lyles, M.A., 2010, 'Absorping the concept of absorptive capacity - How to realize its potential in the organization field', Organization Science 21, 1-21. http://dx.doi.org/10.1287/orsc.1090.0503
Waalkens, J., Jorna, R. \& Postma, T., 2004, 'Absorptive capacity of knowledge intensive business services: The case of architectural and engineering SMEs', Frontiers of e-Business Research 1, 444-458, Tampere University, Tampere.

Wiesner, R., McDonald, J. \& Banham, H.C., 2007, 'Australian small and medium sized enterprises (SMEs): A study of high performance managment practices', Journal of Management and Organization 13(3), 227-248. http://dx.doi.org/10.5172/ jmo.2007.13.3.227

Wiklund, J. \& Shepherd, D., 2003, 'Knowledge-based resources, entrepreneurial orientation, and the performance of small and medium-sized businesses' Strategic Management Journal 24(13), 1307-1314. http://dx.doi.org/10.1002/ smj.360

Wong, K.Y. \& Aspinwall, E., 2004, 'An empirical study of the important factors for knowledge management adoption in SME sector', Journal of Knowledge Management 9(3), 64-82. http://dx.doi.org/10.1108/13673270510602773

Yao, L., Othman, A., Abdalla, A.N. \& Jing, W., 2011, 'A novel sensemaking model of effective knowledge management within SMEs', African Journal of Business Management 5(11), 4423-4431.

Zahra, S. \& George, G., 2002, 'Absorptive Capacity: A Review, reconceptualization, and extension', Academy of Management Review 27(2), 185-203. 